\title{
Feeding ecology of the culpeo in southern Ecuador: wild ungulates being the main prey
}

\author{
Marta Guntiñas ${ }^{1,2}$, Jorge Lozano ${ }^{1,3}$, Rodrigo Cisneros ${ }^{1,2}$, Carlos Narváez ${ }^{1}$, Jorge Armijos ${ }^{1}$ \\ ${ }^{1}$ Department of Natural Sciences, Basic and Applied Biology Section, Técnica Particular de Loja University, San \\ Cayetano Alto, C/París s/n. Loja 1101608, Ecuador \\ ${ }^{2}$ ESCET, Department of Biology and Geology, Rey Juan Carlos University, C/Tulipán s/n. 28933 Móstoles, Spain \\ ${ }^{3}$ Leuphana University of Lüneburg, Faculty of Sustainability, Institute of Ethics and Transdisciplinary Sustainability \\ Research (IETSR), Scharnhorststraße 1, 21335 Lüneburg, Germany \\ ${ }^{1}$ E-mail:m.guntinas.r@gmail.com
}

Key words: Andes, canids, carnivores, cloud forest, diet, paramo, Podocarpus, trophic diversity

\begin{abstract}
This study details for the first time the food habits of the culpeo or Andean fox (Lycalopex culpaeus) in high areas of the Ecuadorian Andes during a complete annual cycle. Our objective was to identify prey species, calculate their contribution to diet and test for temporal variation. In total, 304 Andean fox scats were collected within the Podocarpus National Park (Loja province, southern Ecuador). By analysing the content of scats 413 prey items were identified and classified into eight prey groups. Subsequently, the frequency of occurrence (FO) for each prey group was calculated per month together with the relative contribution of estimated consumed biomass (CB). In addition, the ShannonWiener's index was calculated as a measurement of monthly diet diversity. The results show a diet dominated by cervids belonging to the Mazama and Pudu genus (70\% FO), followed by small mammals (30\% FO), large rodents (12\% FO), carnivorous species (10\% FO) and lagomorphs (8\% FO). There was temporal variation in the consumption of both deer and small mammals. Cervids also provided the major part of the consumed biomass $(70 \% \mathrm{CB})$, the remaining prey categories each accounted for less than $11 \%$ CB. Negative correlations in consumption were observed between cervids and two other groups, rabbits and small mammals. Trophic diversity values fluctuated throughout the year showing a mean of 1.7. The results obtained show a diets very different from those previously reported; deer being the bulk of the diet instead of rodents or other mammals. The consumption of carnivorous species in the area was also high in comparison with other regions. Overall, this study clearly demonstrates that the culpeo is an important top predator in the highAndean ecosystem.
\end{abstract}

\section{Contents}

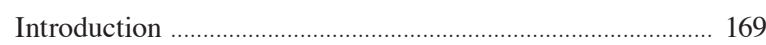

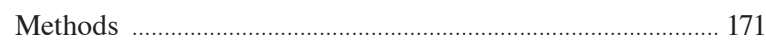

Study area ............................................................................. 171

Collection of culpeo scats ................................................. 171

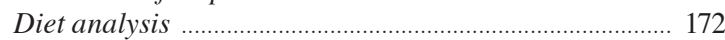

Results 172

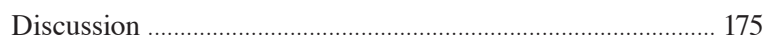

Acknowledgements ............................................................. 177

Refererences ……........................................................... 177

\section{Introduction}

The culpeo or Andean fox (Lycalopex culpaeus, Molina $1782)$ is the second largest canid $(4-13.8 \mathrm{~kg})$ in South America (Jiménez et al., 1995; Jiménez and Novaro, 2004). It is distributed along the Andes Mountain range, from southern Colombia to Tierra del Fuego, Argentina (Jiménez et al., 1995). It is present at low altitudes in the Pacific and Atlantic coasts (Jaksic et al., 1980; Meserve et al., 1987; Medel and Jaksic, 1988; Marquet et al., 1993), and reaches the 4800 meters above sea level (m.a.s.l) in the Andes Mountains (Jiménez et al., 2008). Andean foxes occupy a large variety of habitats and environmental gradients: ranging from arid steppes (Meserve et al., 1987; Martínez et al., 1993; Arim and Jaksic, 2005), high steppes (Marquet et al., 1993; Johnson and Franklin, 1994; Walker et al., 2007; Palacios et al., 2012), dense shrubs (Iriarte et al., 1989), to altered ecosystems (Novaro et al., 2000; Pia et al., 2003) and pine reforested areas (Acosta-Jamett and Simonetti, 2004), or even rainforest (Jiménez et al., 2008).

This species is considered to be a trophic generalist (e.g. Walker et al., 2007). Indeed, culpeos exploit a wide variety of vertebrate, invertebrate and plant species according to their availability (Acosta-Jamett and Simonetti, 2004), although a degree of selectivity has been also reported (Meserve et al., 1987; Iriarte et al., 1989; Martínez et al., 1993; Corley et al., 1995). The culpeo is the most carnivorous of the Neotropical canids (Jiménez and Novaro, 2004), with a diet generally dominated by small mammals, especially rodents (Iriarte et al., 


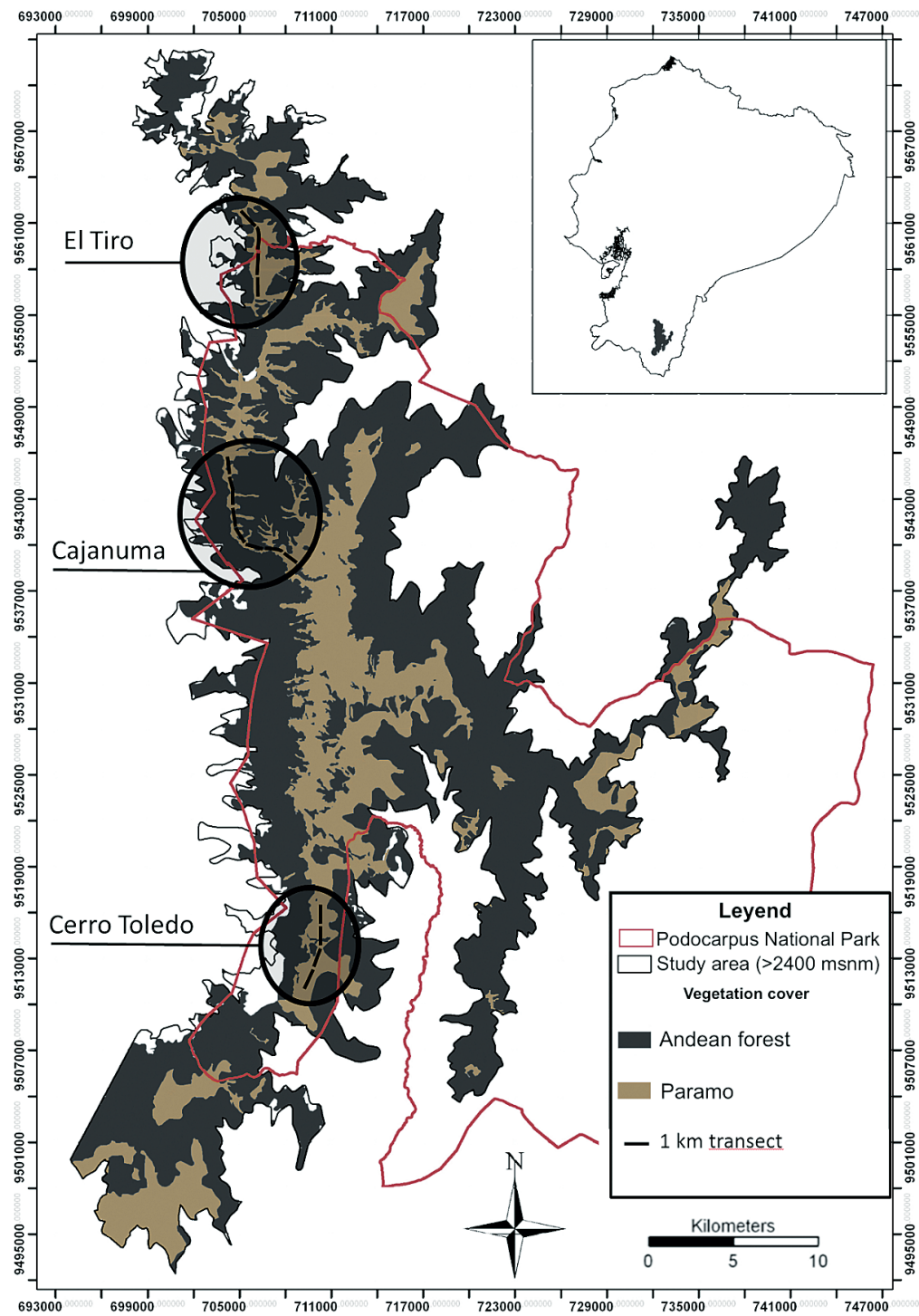

Fig. 1. Location of the study area in Podocarpus National Park (PNP), southern Ecuador. The three main places where the 16 fixed 1-km transects were concentrated are also shown (El Tiro, $4 \mathrm{~km}$; Cajanuma, $8 \mathrm{~km}$ and Cerro Toledo, $4 \mathrm{~km}$ ). Transects are not scaled.
1989; Ebensperger et al., 1991; Jaksic et al., 1992, 1993; Castro et al., 1994; Pia et al., 2003; Correa and Roa, 2005; Achilles, 2007; Pia, 2013). Exotic lagomorphs (i.e. the European hare Lepus europaeus and the wild rabbit Oryctolagus cuniculus) can become important food sources for culpeos (Johnson and Franklin, 1994; Novaro et al., 2000; Pia et al., 2003; Walker et al., 2007; Pia, 2013; Rubio et al., 2013), and arthropods often appear in the culpeo's diet (e.g. Corley et al., 1995; Correa and Roa, 2005; Guzmán-Sandoval et al., 2007; Walter et al., 2007). In addition, birds and reptiles can be considered prey, although studies show their contribution to the diet be variable (Achilles, 2007; Silva et al., 2005; Walker et al., 2007).

The culpeo is a brave predator able to attack large prey such as alpaca calves (Vicugna pacos), vicunas (Vicugna vicugna) and llamas (Lama glama), as observed in Bolivia (Franklin, 1982, in Donadio et al., 2012; Zacari and Pacheco, 2005). In Argentina Andean foxes also prey on lambs (Novaro et al., 2000, 2005), the species being persecuted due to damages produced on livestock (Jiménez and Novaro, 2004). Furthermore, and like other canid species, culpeos can consume different amounts of carrion (Novaro et 
al., 2000; Walker et al., 2007; Stucchi and Figueroa, 2010).

Plants also usually form an important part of the Andean fox's diet (Jaksic et al., 1980; Ebensperger et al., 1991; Cornejo and Jiménez, 2001; Zapata et al., 2005). Plant consumption probably depends on the existing availability of prey (Castro et al., 1994; Silva et al., 2005). Andean foxes are known to be important seed dispersers of mesquite species (Prosopis flexuosa and P. pallida) (Cornejo and Jiménez, 2001; Maldonado et al., 2014) and pepper (Schinus molle) (Castro et al., 1994), although its role as an effective dispersant for other species is unclear (León-Lobos and Kalin-Arroyo, 1994; Silva et al., 2005).

Nevertheless, most studies dealing with the culpeo's diet are from Chile and Argentina, so there are vast regions of South America where the feeding ecology of the species has been poorly studied, including entire countries (with their associated habitats and particular ecological conditions) where the diet is completely unknown. This is the case of Ecuador, where the species has recently been listed as Vulnerable (Tirira, 2011). The culpeo is distributed throughout the country, but it is generally considered to be a canid habiting highlands and cold areas (cloud forests and 'paramos'), between 2600 and 4500 m.a.s.l., along the Andes range (Tirira, 2007). In this important region of the world no systematic and representative study examining the diet of the Andean fox has been published to date.

The aim of this study is to describe the trophic patterns of the Andean fox in the high Andes of southern Ecuador over a complete annual cycle, thus obtaining the first systematic outcome on the species feeding ecology in the country. In particular, it is intended: 1) to identify the culpeo's prey species in the Podocarpus National Park and to describe the annual pattern of frequency in the diet of different prey groups; and 2) to evaluate the temporal variation during the year both in the consumption of prey groups and trophic diversity.

\section{Methods}

\section{Study area}

The study was conducted in the high areas of the Podocarpus National Park (PNP), this being the most important protected area in southern Ecuador (Fig. 1). It is located within the so-called 'Huancabamba depression', which is considered a transition zone between the Northern and Southern Andes mountains because their maximum elevations (3800 m.a.s.l) are the lowest in the Andean range. The PNP occupies 145000 ha of this region, in the provinces of Loja and Zamora-Chinchipe (MAE, 2015). The PNP has a humid-subhumid ombrotype and the temperature varies between 2 and $22{ }^{\circ} \mathrm{C}$. The vegetation consists of tropical rainforest at low altitude, followed by different types of Sub-Andean, Andean and High-Andean forest (i.e. cloud forests) at higher altitudes. Between 2600 (m.a.s.l) and the high peaks (3600 m.a.s.l.) a moorland type habitat (known as 'paramo') appears, occupying a narrow strip along the ridge in a north-south gradient (Rivera, 2007; MAE, 2015). These paramos are characterised by the abundance of rosette and pad plant species: Bambu and Chusquea are the dominant plant genus, alongside Polylepis, Escallonia and Clusia shrub species (see Sierra, 1999). These mountain ecosystems in the PNP are the most humid in Ecuador, with rainfall exceeding 6000 $\mathrm{mm} /$ year, low temperatures and strong winds (Richter, 2003; Rivera, 2007).

\section{Collection of culpeo scats}

This study is based on analysing scat contents to determine the culpeo's diet. It is a non-invasive method that shows what the species real consumes (Putman, 1984; Corbett, 1989) and is widely used for studying the feeding habits of carnivores (e.g. Halter, 1967; Reynolds and Aebischer, 1991; Juarez and Marinho-Filho, 2002; Malo et al., 2004). In Particular, this method has already been used to study the culpeo's diet (e.g. Iriarte et al., 1989; Ebensperger et al., 1991). All accessible areas of paramo in the PNP were sampled for culpeo scat collection. These areas were concentrated in three zones of the PNP known locally as Cajanuma, El Tiro and Cerro Toledo. A different number of fixed 1-km transects (16 in total) were established in each area on existing paths (see Fig. 1). During 2009 each 1-km transect was sampled in search of fresh scats once a month (thus resulting in a total of $192 \mathrm{~km}$ of overall sampling effort), at 30 day intervals and starting in the middle of each month (so that any scat found was assigned to the corresponding sampled month). Previously, a survey to remove old scats was undertaken in all transects. Samplings were always conducted by the same observers, who were well trained prior to starting the fieldwork (Lozano et al., 2013).

Collected scats were stored at $-80{ }^{\circ} \mathrm{C}$ when clearly identified as belonging to Andean foxes. Scats were first identified based on a set of context-based diagnostic characteristics (Romo, 1995; Cornejo and Jiménez, 
2001; Achilles, 2007; Palacios et al., 2012; Pia, 2013), which included location (scats directly on the path or close by), general morphology (canid-like scats, different from those of cats, bears, etc), and diameter (2-3 $\mathrm{cm})$. In addition, genetic analyses were performed in the lab to confirm scat identification. 89 scats were randomly selected from the total sample, and DNA was extracted by applying the QIAGEN QIAamp DNA Stool Mini Kit (QIAGEN, CA.USA). The protocol described by De Barba et al., (2014) was used for mitochondrial DNA amplification. Amplification was successful for $81.2 \%$ of the total sample (i.e. 70 scats), the genetic material being positively identified as belonging to culpeo in all cases. Therefore, observers in the field had a $100 \%$ success rate in the identification of these 70 scats, demonstrating that with good previous training correct identification of culpeo scats based on external features is possible in the area (see Lozano et al., 2013). Hence, no relevant confusion with the scats of other animals inhabiting the same environment, such as pumas (Puma concolor), Andean bears (Tremarctos ornatus) or domestic dogs (Canis familiaris), was assumed.

\section{Diet analysis}

We collected a total of 304 culpeo faeces. Each scat was air dried, soaked in soapy water, and washed through 1-mm and 3-mm sieves, thus disaggregating the content (hair, feathers, bones, hooves, invertebrate and plant remains) for the identification of prey groups (e.g. Ackerman et al., 1984). Determination of mammalian species was performed according to the patterns of cuticle and medulla in the structure of guard hairs (see Arita and Aranda, 1987; Chehébar and Martín, 1989). Hairs present in the scats were compared with those of a reference collection, which accounted for 46 previously collected potential prey species. Likewise, bone remains were compared when necessary with the reference collection located at San Francisco de Quito University. To estimate biomass consumption by culpeos, the mean body mass for the Ecuadorian species identified as prey was obtained from the literature (e.g. Tirira, 2007), and a maximum consumption of $800 \mathrm{~g}$ was assumed considering the culpeo's size (Sillero-Zubiri et al., 2004). For small food items, such as invertebrates and fruits, representative values of biomass were used (e.g. Malo et al., 2004; see Tab. 1).

Food items were classified into eight prey groups (Tab. 1): small mammals, big rodents, armadillos, rabbits, carnivorous (i.e. including marsupial carnivores), cervids, fruits and others (including birds and invertebrates, which were only consumed in small quantities). The relative contribution of each prey item and group to the diet was measured by calculating their frequency of occurrence (FO), i.e. the number of scats in which a given prey item or group was found divided by the total number of scats, expressed as a percentage. Furthermore, the consumed biomass (CB) of each prey group was estimated, and also expressed as a percentage, multiplying the number of each item by its assigned weight and then dividing the result by the total sum of biomass.

Data from the three sampling sites (Fig. 1) were pooled for statistical analyses because sites cannot really be considered as independent areas. Indeed, based on the genetic individualisation of scats, several individuals used more than one site (Authors, unpublished data), so any comparison among sites is rendered meaningless. Then, for the PNP as a whole, G-tests (Sokal and Rohlf, 1981) were performed to search for statistically significant differences in the FO of the eight prey groups in different months. Spearman's correlation coefficients (Moran, 1948) were calculated to test for the existence of relationships between prey groups over time. The Kruskal-Wallis test was conducted to test for differences in the biomass contribution between prey groups. Moreover, the Shannon-Wiener's index (Shannon and Weaver, 1949) was used to measure trophic diversity. Data from November and December were combined to get a representative sample size. All statistical analyses were performed using the software Statistica 10 (StatSoft 2011).

\section{Results}

We identified a total of 413 prey items in 304 scats (Tab. 1), collected during a year of sampling. A total of 16 mammalian species were identified, which were by far the most consumed prey. Indeed, mammals were present in $100 \%$ of the scats analysed. Cervids were the most consumed prey group, with a frequency of occurrence (FO) of $71 \%$. The next most significant group in terms of FO was small mammals (26\%), followed by big rodents (12\%), carnivorous (10\%) and rabbits (8\%) (Tab. 1). Birds and fruits were poorly represented, both being found in only $3 \%$ of the scats analysed. Contributions of consumed biomass in terms of percentage were similar, except for small mammals $(0.95 \% \mathrm{CB})$, others $(0.11 \% \mathrm{CB})$ and fruits $(0.02 \% \mathrm{CB})$, with values much lower than those provided by FO. 


\begin{tabular}{|c|c|c|c|c|c|}
\hline \multicolumn{2}{|l|}{ Prey items } & $\mathbf{n}$ & Weight (g) & FO \% & CB \% \\
\hline \multicolumn{2}{|c|}{ SMALL MAMMALS } & 80 & & 26.32 & 0.95 \\
\hline \multirow[t]{3}{*}{ Caenolestidae } & Caenolestes caniventer & 23 & 0.037 & 7.57 & 0.34 \\
\hline & Caenolestes fuliginosus & 32 & 0.028 & 10.53 & 0.36 \\
\hline & Caenolestes spp. & 1 & 0.030 & & 0.01 \\
\hline Soricidae & Cryptotis montivaga & 14 & 0.012 & 4.61 & 0.07 \\
\hline Cricetidae & Cricetidae spp. & 10 & 0.040 & 3.29 & 0.16 \\
\hline \multicolumn{2}{|l|}{ BIG RODENTS } & 37 & & 12.17 & 10.22 \\
\hline Cuniculidae & Cuniculus paca & 18 & 9000 & 5.92 & 5.80 \\
\hline Dasyproctidae & Dasyprocta punctata & 9 & 4000 & 2.96 & 2.90 \\
\hline Sciuridae & Sciurus spp & 10 & 0.375 & 3.29 & 1.51 \\
\hline \multicolumn{2}{|l|}{ CARNIVOROUS } & 30 & & 9.87 & 9.38 \\
\hline Mephitidae & Conepatus semistriatus & 1 & 2400 & 0.33 & 0.32 \\
\hline \multirow[t]{2}{*}{ Didelphidae } & Didelphis marsupialis/pernigra & 10 & 1500 & 3.29 & 3.22 \\
\hline & Marmosa robinsoni & 1 & 0.076 & 0.33 & 0.03 \\
\hline Felidae & Puma concolor & 3 & 75000 & 0.99 & 0.97 \\
\hline Procyonidae & Nasuella olivacea & 15 & 1300 & 4.93 & 4.84 \\
\hline ARMADILLOS & Dasypus novemcinctus & 4 & 5200 & 1.32 & 1.29 \\
\hline \multirow[t]{2}{*}{ CERVIDS } & Mazama rufina & 171 & 11000 & 56.25 & 54.82 \\
\hline & Pudu mephistophiles & 46 & 7000 & 15.13 & 15.16 \\
\hline RABBITS & Sylvilagus brasiliensis & 25 & 0.95 & 8.22 & 8.06 \\
\hline \multicolumn{2}{|l|}{ OTHERS } & 11 & & 3.62 & 0.11 \\
\hline \multirow[t]{2}{*}{ Insecta } & Coleopterans & 1 & 1 & 0.33 & 0.00 \\
\hline & Myriapods & 1 & 1 & 0.33 & 0.00 \\
\hline \multirow[t]{2}{*}{ Birds } & Psittacidae & 1 & 40 & 0.33 & 0.02 \\
\hline & Other birds & 8 & 10 & 2.63 & 0.08 \\
\hline \multicolumn{2}{|l|}{ FRUITS } & 9 & 5 & 2.96 & 0.02 \\
\hline \multicolumn{2}{|c|}{ Total number of scats } & 304 & & & \\
\hline \multicolumn{2}{|c|}{ Total prey items } & 413 & & & \\
\hline
\end{tabular}

Table 1. Culpeo diet in the Podocarpus National Park (Andean highlands of southern Ecuador). The number of each prey items found in scats (n), the weight (biomass) assigned to each prey item (in grams), the frequency of occurrence (FO, in percentage), and the estimated consumed biomass ( $\mathrm{CB}$, in percentage) for each prey item, are reported. To estimate $\mathrm{CB}$ a maximum of $800 \mathrm{~g}$ was established for the culpeo.
Considering prey species, the little red brocket deer (M. rufina) showed the highest FO, followed by the northern pudu (Pudu mephistophiles). The most consumed small mammals were marsupials: the gray-bellied shrew opossum (Caenolestes caniventer) and the silky shrew opossum (C.fuliginosus). Big rodents were also important for the Andean fox's diet, especially the spotted paca (Cuniculus paca) and the central american agouti (Dasyprocta punctata). The tapeti or forest rabbit (Sylvilagus brasiliensis) is the only lagomorph present in the region and it also preyed upon (8.2\% FO). The nine-banded armadillo (Dasypus novemcinctus) also appeared in the diet (1.32\% FO). A focal point of the culpeo's diet was the relatively high consumption of carnivores and similar (i.e. Didelphidae), such as the western mountain coati (Nasuella olivaceae), the striped hog-nosed skunk (Conepatus semistriatus), and opossums (Didelphis marsupialis and/or D. pernigra), accounting for $9.8 \%$ FO. Interestingly, remains of puma (Puma concolor) were also found in three scats (Tab. 1).

Temporal variation was found in the most consumed group (i.e. cervids) $(\mathrm{n}=217, \mathrm{G}=19.7$, d.f $=10, p=0.03)$, where the highest consumption occurred during April, May and June (Fig. 2). Likewise, in the second most consumed group, small mammals, temporal variation was also found ( $\mathrm{n}=80, \mathrm{G}=27.92$, d.f $=10, p=0.002)$, with an intense consumption in August (Fig. 2). For the forest rabbit a higher consumption during April and June was recorded, showing a marginally non-significant difference $(\mathrm{n}=25, \mathrm{G}=17.46$, d.f. $=10, p=0.06)$. For the rest of the prey groups no temporal variations in consumption were found: big rodents $(n=37, G=10.10$, 


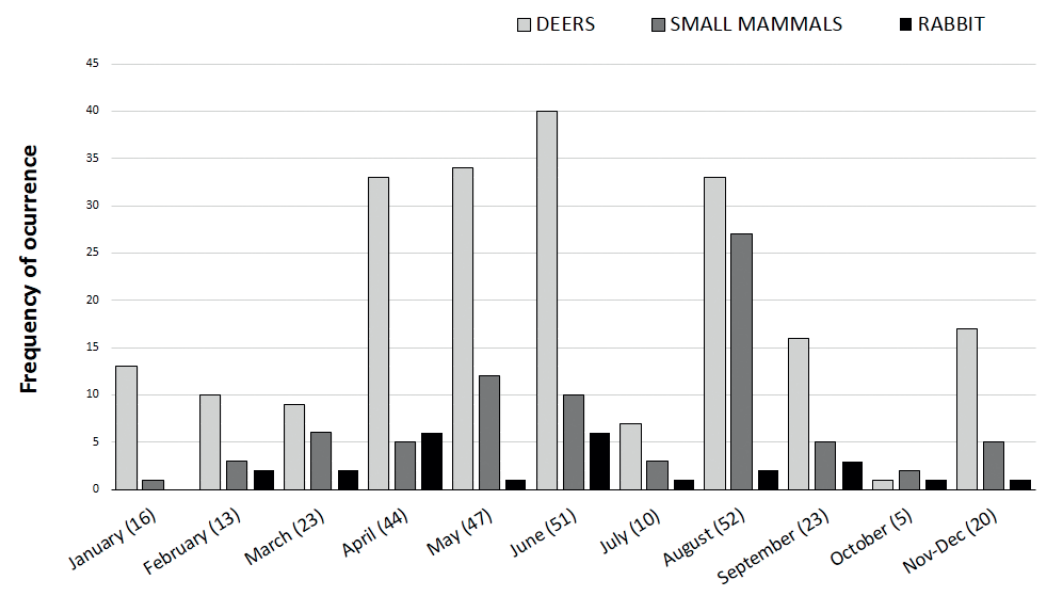

Figure 2. Frequency of occurrence (FO) across months of the culpeo's prey groups showing temporal variation in the high areas of the Podocarpus National Park (PNP): cervids, small mammals and rabbits. In brackets the number of scats found per month is shown.

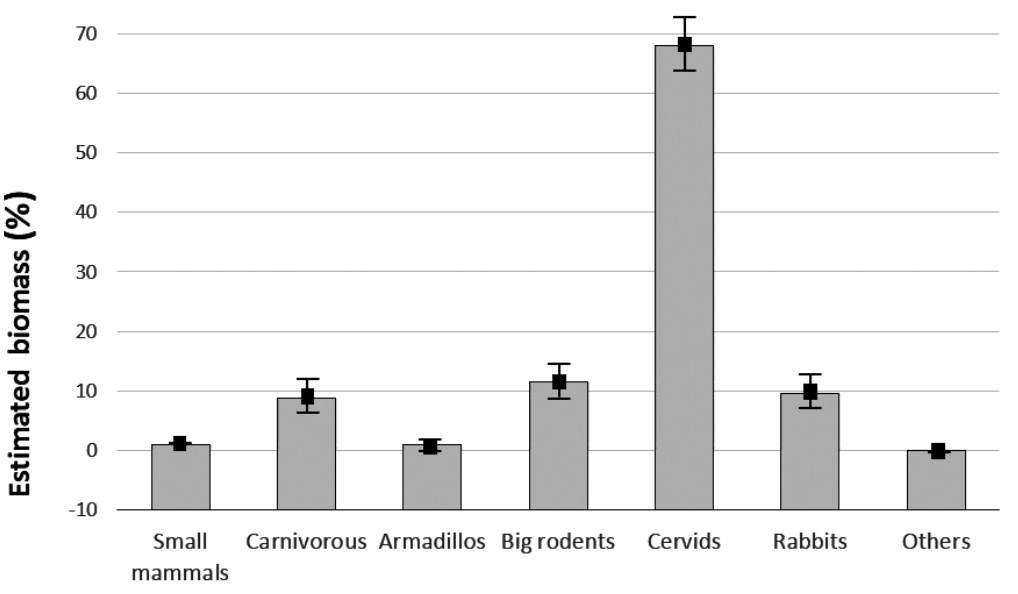

Figure 3. Annual average of prey group contributions in estimated consumed biomass ( $\mathrm{CB}$, expressed as percentage) to the culpeo's diet in the high areas of the Podocarpus National Park (PNP, southern Ecuador).

\begin{tabular}{|c|c|c|}
\hline Small mammals & $\square$ Carnivorous & 皿 Armadillos \\
\hline$\square$ Cervids & -⿴囗大 Rabbits & Others \\
\hline
\end{tabular}

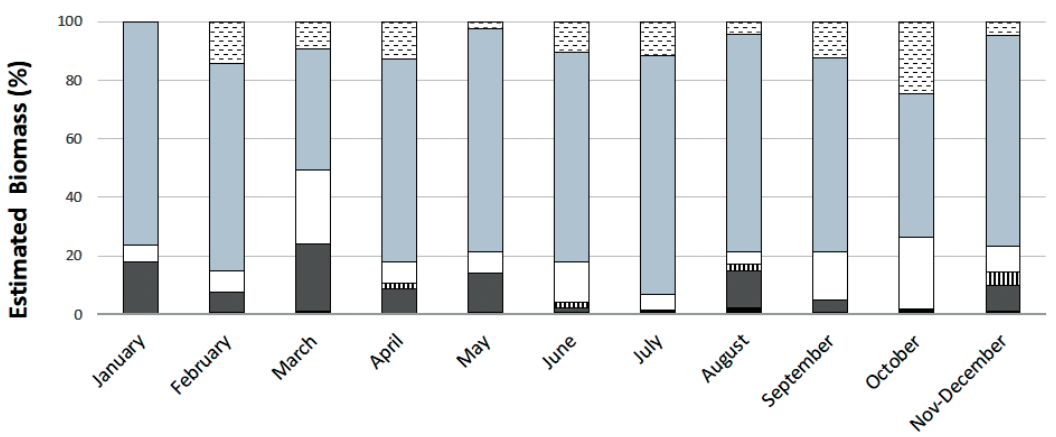

Figure 4. Contribution in estimated consumed biomass ( $\mathrm{CB}$, expressed as percentage) across months of the culpeo's prey groups in the high areas of the Podocarpus National Park (PNP, southern Ecuador).

d.f $=10, p=0.43)$, carnivorous $(\mathrm{n}=30, \mathrm{G}=14.1$, d.f $=$ $10, p=0.17)$, armadillos $(\mathrm{n}=4, \mathrm{G}=5.48$, d.f $=10, p=$ $0.86)$, fruits $(\mathrm{n}=9, \mathrm{G}=14.12$, d.f $=10, p=0.16)$ and others $(\mathrm{n}=11, \mathrm{G}=7.00$, d.f $=10, p=0.72)$. Over time significant negative Spearman correlations were found between the consumption of deer and small mammals (January $=-0.54, \mathrm{p}<0.05$; March $=-0.52, \mathrm{p}<0.05$ : August $=-0.55, \mathrm{p}<0.05$; September $=-0.67, \mathrm{p}<0.05$ ), as well as between the consumption of deer and rabbits $($ February $=-0.79, \mathrm{p}<0.05$; April $=-0.54, \mathrm{p}<0.05)$. 


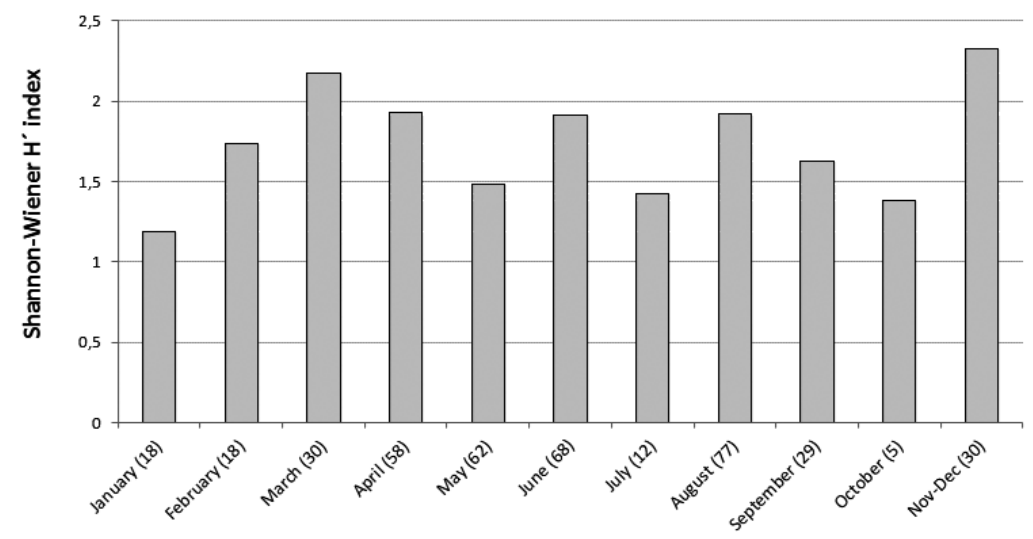

Figure 5. Trophic diversity of culpeos across months in the high areas of the Podocarpus National Park (PNP, southern Ecuador), according to the ShannonWiener's index. In brackets the number of prey items per month is shown.

In relation to the annual average contribution of biomass there was a significant difference between prey groups $(\mathrm{H}(6, \mathrm{~N}=77)=55.46 ; \mathrm{p}<0.001)$, given that a high cervid contribution was found (Fig. 3). Big rodents, rabbits and carnivorous were the next most significant groups, showing similar contributions (around $10 \% \mathrm{CB}$ ). Finally, contribution to consumed biomass by the resting groups was minimal. Throughout the year a clear predominance of deer consumed biomass is observed, which decreases in March just when the biomass contribution of big rodents and carnivorous increases (see Fig. 4). Although in variable values, rabbits, carnivorous, and big rodents provided biomass in considerable amounts during all months, whereas the contribution of small mammals and other food items was always very low (Fig. 4).

In addition, values given by the Shannon-Wiener's index as a measurement of the culpeo's trophic diversity fluctuated throughout the year, showing an average of 1.7. January presented the lowest diversity value (1.2), whereas it doubled in March (2.2) (Fig. 5).

\section{Discussion}

The culpeo has been described as a generalist species, able to harness a diversity of food resources (Jiménez et al., 2008). In the high areas of the PNP the species has a predominantly carnivorous diet (98\% of items are of animal origin). In this sense, the results match those reported in the pioneering studies of Crespo and Carlo (1963) in Argentina (prey animals with 96.9\% FO), and Fugger (1979) in Chile (with 95\% and 97\% FO in Ayacucho and Cuzco, respectively). However, the trophic pattern found in southern Ecuador, regarding the type of prey and its frequency in the diet, is completely different from those reported to date.
Indeed, in contrast to studies carried out in other areas of Latin America, the culpeo in southern Ecuador seems to prey mainly on wild ungulates (Mazama and $P u d u$ genus), which were the bulk of the diet in terms of both frequency of occurrence and biomass contribution. Therefore, the high representation of their remains in the scats (i.e. 70\% FO) supports the idea that the culpeo actively hunts deer, being able to be an important predator of these species in the region. This pattern differs from all published studies, where cervids have little or even no representation. For example, in a study of the culpeo's diet in the paramos of Peru (Romo, 1995), where deer were present, no deer remains were found in the culpeo scats. In the PNP cervids belonging to the Mazama and $P u d u$ genus were the most consumed prey throughout the year, with a peak frequency in June, and high values for FO during April, May and August. Perhaps this pattern relates to a higher temporal availability of pregnant females, cubs and juveniles during these months. In Ecuador it is thought that deer can breed throughout the year, but unfortunately data on deer phenology in the different Ecuadorian regions is lacking. Months showing high consumption of deer could also coincide with a period of low availability of other potential prey. Small mammals were the second most consumed prey group in terms of FO (although its contribution to consumed biomass was apparently irrelevant) and consumption levels were particularly high during August, perhaps indicating a significant temporal variation in their abundance, population age structure or mean body weight throughout the year (Malo et al., 2013). Moreover, it has been observed that the higher the consumption of deer the lower the consumption of small mammals (precisely during January, February, March and September). Taking all the above into account, this variation could indicate temporary changes in the availability of these prey groups (Malo et al., 2013). 
It is likely that the high consumption of deer (and of other animals such as carnivorous) in the PNP is in part due to the culpeo's scavenging activity. Although scavenging on deer was not detected in Peru (Romo, 1995), general scavenging activity by culpeos has been reported on many occasions (Walker et al., 2007). However, PNP rangers have observed direct predation of culpeos on deer (PNP staff, pers. comm.), which is not strange when considering that consumed deer were mediumsmall species, mainly Mazama rufina $(8-14 \mathrm{~kg})$ and Pudu mephistophiles (5-10 kg) (see Tirira, 2007). Indeed, predation and attacks on animals of equal or even greater size, such as offspring and subadults of alpacas, vicuñas, llamas and guanacos, as well as sheep and goats, have been reported in Argentina and Chile (Novaro et al., 2000; Pia, 2003, 2004; Zacari and Pacheco, 2005). For example, Novaro et al. (2009) photographed and verified an episode of direct attack on young guanacos (33 kg), also observing continuous reactions of defense by guanaco family groups as soon as culpeos were sighted. Apparently, any animal weighing less than $35 \mathrm{~kg}$ can be potential prey for culpeos, given that this predator is able to kill individuals 6.6 times heavier than itself (see Jiménez and Novaro, 2004). Therefore, although culpeos could take deer meat from carcasses (left behind by the scarce numbers of pumas living in the area, for instance), it seems certain that in the PNP they often actively hunt deer.

The forest rabbit was the fourth most consumed species (showing a similar significance in biomass contribution) by the Andean fox. It is known that lagomorphs are important prey for this carnivore, with numerous studies highlighting the consumption of the European hare (Johnson and Franklin, 1994; Corley et al., 2005; Walker et al., 2007) and the European or wild rabbit (Iriarte et al., 1989; Rubio et al., 2013). It is interesting to note that only in Ecuador and northern Peru do the culpeo and the forest rabbit overlap in their respective ranges of distribution, the latter being the only lagomorph present in Ecuador. The consumption of forest rabbits tends to present temporal variation, showing FO peaks in the months of April and June (as with deer, although FO values for rabbits are much smaller). In fact, a negative correlation appears between the consumption of cervids and that of rabbits during April and February, which seems to be a trend for the remaining months. As previously commented in relation to deer, it is possible that the consumption pattern mimics the variation in rabbit availability in the environment (for example, due to potential seasonal breeding patterns of rabbits, although unfortunately no data is available concerning rabbit reproduction in the area).

This study also reports a new pattern found in relation to the consumption of carnivorous species (Palomares and Caro, 1999), which show a FO of around $10 \%$ (and a biomass contribution of 9\%). In a few previous studies examining culpeo's diet, carnivorous species are described as prey in less than 3\% FO in the culpeo diet: for example, in Argentina Johnson and Franklin (1994) recorded the consumption of patagonian hog-nosed skunk (Conepatus humboldti) with an $0.8 \%$ FO; Walker et al. (2007) used the carnivorous taxon as a consumed group with an appearance in faeces of 2.5\%; while in Zapata et al. (2005) this prey group represents $1.8 \%$ of the FO. Thus, the present work reports the highest value of consumption of carnivorous species, including those of medium size such as the Andean coati, the skunk, and also species of the genus Didelphis. In addition, hair remains of puma were found in scats collected during different samplings and times, thus belonging to three different individuals. In fact, puma remains were also found in the culpeo's diet elsewhere (see Pia, 2013). There are two possible explanations for this finding: one, pumas were consumed as carrion (the most probable if these individuals were adults); and two, there was active predation on young pumas. In support of the latter it is known that coyotes kill adult bobcats (see Palomares and Caro, 1999), whose sizes could be similar in some cases to those of adult culpeos (especially males) and young pumas (especially females). Because these felids can kill culpeos (Pacheco et al., 2004; De Oliveira and Pereira, 2014), young pumas could be killed in turn by adult culpeos if given the opportunity, as a culpeo's strategy for reducing the risk of intra-guild predation (e.g. Palomares and Caro, 1999). However, having only the evidence of hair remains in scats we were unable to differentiate between the two possibilities.

Interestingly, we have not found remains of livestock in scats, despite the presence of livestock in the PNP (cattle, horses, poultry, etc). It is possible that due to the high density and availability of wild prey in the PNP, attacks from Andean foxes to livestock do not occur, as often happens with large predators and other canid species (e.g. Imbert et al., 2016). Considering other prey groups, it is also notable that in the PNP bird consumption seems minimal $(2.6 \%$ FO). Again, this pattern significantly differs from those found during other research, where birds attain a FO of almost 12\% (Marquet et al., 1993; Romo, 1995; Walker et al., 2007). In the case of the nine-banded armadillo the FO found $(1.3 \%)$ was similar to that described for other species of 
the same family (see Novaro et al., 2000; Zapata et al., 2005). The consumption of invertebrates was also low ( $0.7 \%$ FO). The importance of this group for the culpeo differs greatly among studies, as it is present in some (Ebensperger et al., 1991; Correa and Roa, 2005; Achilles, 2007; Guzmán-Sandoval et al., 2007) but not in others (Leon-Cobos 1994; Pia, 2013). Finally, the estimated biomass provided by birds, armadillos and invertebrates was almost irrelevant.

Fruit consumption showed low values (3\% FO) compared to those observed in other studies, where the FO reaches values of almost 70\% (Romo, 1995). Although this is not the only study where a low consumption is described (see Marquez et al., 1993), the culpeo in the PNP did not use this resource significantly at any particular time of the year, showing instead a markedly carnivorous diet. Some studies have observed a negative correlation between consumption of fruits and abundance of rodent (Castro et al., 1994; Silva et al., 2005) and invertebrate (Cornejo and Jiménez, 2001) prey availability. In the desert of Peru, Romo (1995) found a 70\% FO of Vaccinium berries in the culpeo's diet. This source of food is also abundant in the PNP, but consumption levels remain low. Thus, this could indicate a continuous supply of their most consumed prey throughout the year. Indeed, deer have long life cycles and their populations fluctuate less than those of smaller species such as rodents or rabbits. However, fruits might be more relevant in the diet if longer time series are considered, given that it has been observed that its importance can vary between years (Arim and Jaksic, 2005; Silva et al., 2005). Therefore, more studies are needed to assess the role of the Andean fox as a seed disperser in the high-Andean ecosystem.

In the study area the trophic diversity of Andean foxes fluctuated across time. During most of the year Shannon-Wiener's index values remain below the average (i.e. $\mathrm{H}^{\prime}=1.7$ ), showing a relatively low dietary diversity. In fact, diversity values are higher than, or close to, the mean value during only four months. March was the month showing the highest value of trophic diversity, while January presented the lowest one, when the diet was clearly dominated by cervids. Lower trophic diversity values $\left(\mathrm{H}^{\prime}=1.2\right.$ and $\left.\mathrm{H}^{\prime}=1.3\right)$ were described in Central Chile (see Rubio et al., 2013), whereas a high diversity value $\left(\mathrm{H}^{\prime}=3\right)$ was found in the south of Peru (Cornejo and Jiménez 2001).

The results of this work, which is the first systematic approach to the feeding ecology of the Andean fox in Ecuador, show that the species could behave as a facultative specialist rather than a generalist (see Glasser
1982, 1984). This hypothesis seems more likely when studies from other countries are also taken into account. Thus, as described for other carnivores such as the European wildcat (Felis silvestris) (Malo et al., 2004; Lozano et al., 2006), the red fox (Vulpes vulpes) (DelibesMateos et al., 2008) and the pine marten (Martes martes) (Rosellini et al., 2008), the culpeo could specialise on different prey groups or mammal species according to their availability. In contrast to other regions, in the PNP the culpeo has specialised in consuming cervids (probably including carrion), although small mammals or alternative food types could become the bulk of the diet if deer availability decreases. Consequently more studies on feeding ecology, in particular accounting for prey availability, are needed to test this hypothesis. Furthermore, the important consumption of carnivorous species in the PNP seems to demonstrate that the culpeo is a top predator in the high Andes. If so, we can speculate that the culpeo, along with the puma, could regulate the populations of meso-predators, having a strong influence on both carnivore community structure and the functioning of the ecosystem functioning (see Ripple $e t$ al., 2014).This hypothesis has important consequences for conservation purposes. Nevertheless, more studies on population dynamics and the effects upon food-webs will be needed to gain a better understanding of the ecological role played by the culpeo, or Andean fox, in the high mountains of Ecuador.

\section{Acknowledgements}

Jorge Lozano was supported by a Prometeo Fellowship from SENESCYT, the national agency for Education and Science of the Government of Ecuador. We would like to express our gratitude to the Regional Ministry of Environment $\mathrm{N}^{\circ} 7$ in Loja for facilitating research permits, and also to their rangers for their help with logistics and fieldwork. We also thank the Universidad San Francisco de Quito for sharing its reference collection with us, and Lisette Waits (University of Idaho, USA) and Daniela Arias for providing genetic information on scats. Special thanks also go to Danilo Patiño, a student, for his help in the laboratory. Three anonymous referees provided comments which greatly improved the final manuscript. This research was carried out with the economic support of the Universidad Técnica Particular de Loja (UTPL), Ecuador.

\section{References}

Achilles NT. 2007. Dieta estival del culpeo (Pseudalopex culpaeus, Molina 1782) en Nevados de Chillán, centro-sur de Chile. M.Sc. Thesis, Facultad de Ciencias Veterinarias. Universidad Austral de Chile, Chile. 
Acosta-Jamett G, Simonetti JA. 2004. Habitat use by Oncifelis guigna and Pseudalopex culpaeus in a fragmented forest landscape in central Chile. Biodiversity and Conservation, 13(6): 1135-1151.

Ackerman BB, Lindzey FG, Hemker TP. 1984. Cougar food habits in southern Utah. The Journal of Wildlife Management, 48(1): 147-155.

Arim M, Jaksic FM. 2005. Productivity and food web structure: association between productivity and link richness among top predators. Journal of Animal Ecology, 74(1): 31-40.

Arita H, Aranda M. 1987. Técnicas para el estudio y clasificación de los pelos. Instituto Nacional de Investigaciones sobre Recursos Bióticos, Xalapa, Veracruz. Cuadernos de divulgación INIREB, 32: 21.

Castro SA, Silva SI, Meserve PL, Gutierrez JR, Contreras LC, Jaksic FM. 1994. Frugivoría y dispersión de semillas de pimiento (Schinus molle) por el zorro culpeo (Pseudalopex culpaeus) en el Parque Nacional Fray Jorge (IV Región, Chile). Revista Chilena de Historia Natural, 67(2): 169-176.

Chehébar C, Martín S. 1989. Guía para el reconocimiento microscópico de los pelos de los mamíferos de la Patagonia, Doñana. Acta Vertebrata, 16 (2): 247-291.

Corbett LK. 1989. Assessing the diet of dingoes from feces: a comparison of 3 methods. Journal of Wildlife Management, 53: 343-346.

Corley JC, Fernandez GJ, Capurro AF, Novaro AJ, Funes MC, Travaini A. 1995. Selection of cricetine prey by the culpeo fox in Patagonia: a differential prey vulnerability hypothesis. Mammalia, 59(3): 315-326.

Cornejo A, Jiménez P. 2001. Dieta del zorro andino Pseudalopex culpaeus (Canidae) en el matorral desértico del sur del Perú. Revista de Ecología Latino Americana, 8: 01-09.

Correa P, Roa A. 2005. Relaciones tróficas entre Oncifelis guigna, Lycalopex culpaeus, Lycalopex griseus y Tyto alba en un ambiente fragmentado de la zona central de Chile. Mastozoología neotropical, 12(1): 57-60.

Crespo JA, de Carlo J. 1963. Estudio ecológico de una población de zorros colorados Dusicyon culpaeus (Molina) en el oeste de la provincia de Neuquen. Revista del Museo Argentino de Ciencias Naturales Bernardina Rivadavia e Instituto Nacional De Investigacion de Ciancias Naturales-ecologia, 1(1): 56.

De Barba M, Adams JR, Goldberg CS, Stansbury CR, Arias D, Cisneros R, Waits LP. 2014. Molecular species identification for multiple carnivores. Conservation Genetics Resources, 6(4): 821-824.

De Oliveira TG, Pereira JA. 2014. Intraguild predation and interspecific killing as structuring forces of carnivoran communities in South America. Journal of Mammalian Evolution, 21(4), 427-436.

Delibes-Mateos M, de Simon JF, Villafuerte R, Ferreras P. 2008. Feeding responses of the red fox (Vulpes vulpes) to different wild rabbit (Oryctolagus cuniculus) densities: a regional approach. European Journal of Wildlife Research, 54: 71-78.

Donadio E, Buskirk SW, Novaro AJ. 2012. Juvenile and adult mortality patterns in a vicuña (Vicugna vicugna) population. Journal of Mammalogy, 93(6): 1536-1544.

Ebensperger LA, Mella JE, Simonetti JA. 1991. Trophic-niche relationships among Galictis cuja, Dusicyon culpaeus, and Tyto alba in central Chile. Journal of Mammalogy, 72(4): 820-823.
Franklin WL. 1982. Biology, ecology, and relationship to man of the South American camelids. Mammalian Biology in South America, 6: 457-489.

Fugger B. 1979. Zur Ernährung Sbiologie Und Taxonomie Des Andenfuchses, Dusicyon Culpaeus (Molina, 1882) Im Peruanischen Hochland. 1979. M.Sc. Thesis. Diplomarbeit Fakultat Fûr Biologie. Ruprecht-Karl-Universitat. Heidelberg.

Glasser JW. 1982. A theory of trophic strategies: the evolution of facultative specialists. Ecology, 63: 250-262.

Glasser JW. 1984. Evolution of efficiencies and strategies of resource exploitation. Ecology, 65: 1570-1578.

Guzmán-Sandoval J, Sielfeld W, Ferrú M. 2007. Dieta de Lycalopex culpaeus (Mammalia: Canidae) en el extremo norte de Chile (Región de Tarapacá). Gayana, 71(1): 1-7.

Halter DF. 1967 Some aspects in the ecology of the black bear (Ursus americanus) in interior Alaska. M.Sc. Thesis. Univ. of Alaska, Fairbanks.

Imbert C, Caniglia R, Fabbri E, Milanesi P, Randi E, Serafini M, Torretta E, Meriggi A. 2016. Why do wolves eat livestock? Factors influencing wolf diet in northern Italy. Biological Conservation, 195: 156-168.

Iriarte JA, Jiménez JE, Contreras LC, Jaksic FM. 1989. Smallmammal availability and consumption by the fox, Dusicyon culpaeus, in central Chilean scrublands. Journal of Mammalogy, 70(3): 641-645.

Jaksic FM, Schlatter RP, Yáñez JL. 1980. Feeding ecology of central Chilean foxes, Dusicyon culpaeus and Dusicyon griseus. Journal of Mammalogy, 61(2): 254-260.

Jaksic FM, Jiménez JE, Castro SA, Feinsinger P. 1992. Numerical and functional response of predators to a long-term decline in mammalian prey at a semi-arid Neotropical site. Oecologia, 89(1): 90-101.

Jaksic FM, Meserve PL, Gutiérrez JR, Tabilo EL. 1993. The components of predation on small mammals in semiarid Chile: preliminary results. Revista Chilena de Historia Natural, 66: 305-321.

Jiménez JE, Tabilo EL, Jaksic FM. 1995. Body size of Chilean foxes: a new pattern in light of new data. Acta Theriologica, 40: 321-326.

Jiménez JE, Novaro AJ. 2004. Culpeo (Pseudalopex culpaeus). In: Sillero-Zubiri, C., Hoffmann, M., Macdonald, D.W. (Eds.), Canids: Foxes, Wolves, Jackals and Dogs. Status Survey and Conservation Action Plan. IUCN/SCC Canid Specialist Group, Gland and Cambridge. pp. 44-49.

Jiménez JE, Lucherini M, Novaro AJ. 2008. Pseudalopex culpaeus. The IUCN Red List of Threatened Species 2008: e. T6929A12816382. In: http://dx.doi.org/10.2305/IUCN.UK. 2008.RLTS.T6929A12816382. Downloaded on 12 November 2016.

Johnson WE, Franklin WL. 1994. Role of body size in the diets of sympatric gray and culpeo foxes. Journal of Mammalogy, 75(1): 163-174.

Juarez KM, Marinho-Filho J. 2002. Diet, habitat use, and home ranges of sympatric canids in central Brazil. Journal of Mammalogy, 83(4): 925-933.

Maldonado DE, Pacheco LF, Saavedra LV. 2014. Legitimidad en la dispersión de semillas de algarrobo (Prosopis flexuosa, Fabaceae) por zorro andino (Lycalopex culpaeus, Canidae) en el Valle de La Paz (Bolivia). Ecología en Bolivia, 49(2): 93-97. 
Malo AF, Lozano J, Huertas DL, Virgós E. 2004. A change of diet from rodents to rabbits (Oryctolagus cuniculus). Is the wildcat (Felis silvestris) a specialist predator? Journal of Zoology, 263(04): 401-407.

Malo AF, Godsall B, Prebble C, Grange Z, McCandless S, Taylor A, Coulson T. 2013. Positive effects of an invasive shrub on aggregation and abundance of a native small rodent. Behavioral Ecology, 24 (3): 759-767.

Marquet PA, Contreras LC, Torresmura J, Silva SI, Jaksic FM. 1993. Food habits of Pseudalopex foxes in the Atacama Desert, pre-Andean ranges, and the high-Andean plateau of northernmost Chile. Mammalia, 57(1): 131-135.

Martínez DR, Rau JR, Jaksic FM. 1993. Respuesta numérica y selectividad dietaria de zorros (Pseudalopex spp.) ante una reducción de sus presas en el norte de Chile. Revista Chilena de Historia Natural, 66: 195-202.

Medel R, Jaksic FM. 1988. Ecología de los cánidos sudamericanos: una revisión. Revista Chilena de Historia Natural, 61(1): 67-79.

Meserve PL, Shadrick EJ, Kelt DA. 1987. Diets and selectivity of two Chilean predators in the northern semi-arid zone. Revista Chilena de Historia Natural, 60(1): 93-99.

Ministerio del Ambiente Ecuador (MAE): Parque Nacional Podocarpus. Aviable from: http://www.ambiente.gob.ec/parquenacional-podocarpus/ (4 April 2016).

Moran PAP. 1948. Rank correlation and permutation distributions. Biometrika, 44: 142-144.

Novaro AJ, Funes MC, Walker RS. 2000. Ecological extinction of native prey of a carnivore assemblage in Argentine Patagonia. Biological Conservation, 92(1): 25-33.

Novaro AJ, Funes MC, Walker RS. 2005. An empirical test of source-sink dynamics induced by hunting. Journal of Applied Ecology, 42(5): 910-920.

Novaro AJ, Moraga CA, Briceño C, Funes MC, Marino A. 2009. First records of culpeo (Lycalopex culpaeus) attacks and cooperative defense by guanacos (Lama guanicoe). Mammalia, 73(2), 148-150.

León-Lobos PM, Kalin-Arroyo MT. 1994. Germinación de semillas de Lithrea caustica (Mol.) H. et A. (Anacardüiceae) dispersadas por Pseudalopex spp.(Canidae) en el bosque esclerófilo de Chile central. Revista Chilena de Historia Natural, 67: 59-64.

Lozano J, Moleón M, Virgós E. 2006. Biogeographical patterns in the diet of the wildcat, Felis silvestris Schreber, in Eurasia: factors affecting the trophic diversity. Journal of Biogeography 33(6): 1076-1085.

Lozano J, Virgós E, Cabezas-Díaz S. 2013. Monitoring European wildcat populations using scat surveys in central Spain: Are population trends related to wild rabbit dynamics or to landscape features? Zoological Studies, 52(1): 16.

Pacheco LF, Lucero A, Villca M. 2004. Dieta del puma (Puma concolor) en el Parque Nacional Sajama, Bolivia y su conflicto con la ganadería. Ecología en Bolivia, 39(1): 75-83.

Palacios R, Walker RS, Novaro AJ. 2012. Differences in diet and trophic interactions of Patagonian carnivores between areas with mostly native or exotic prey. Mammalian BiologyZeitschrift für Säugetierkunde, 77(3): 183-189.

Palomares F, Caro TM. 1999. Interspecific killing among mammalian carnivores. American Naturalist, 153: 492-508.

Pia MV, López MS, Novaro AJ. 2003. Efectos del ganado sobre la ecología trófica del zorro culpeo (Pseudalopex culpaeus smithersi) (Carnivora: Canidae) endémico del centro de Argentina. Revista Chilena de Historia Natural, 76(2): 313-321.

Pia MV. 2013. Trophic interactions between puma and endemic culpeo fox after livestock removal in the high mountains of central Argentina. Mammalia, 77(3): 273-283.

Putman RJ. 1984. Facts from faeces. Mammal Review, 14(2), 79-97.

Ripple WJ, Estes JA, Beschta RL, Wilmers CC, Richie EG, Hebblewhite M, Berger J, Elmhagen B, Letnic M, Nelson MP, Schmitz OJ, Smith DW, Wallach AD, Wirsing AJ. 2014. Status and ecological effects of the world's largest carnivores. Science, 343 (6167): 1241484.

Reynolds JC, Aebischer NJ. 1991 Comparison and quantification of carnivore diet by faecal analysis: a critique, with recommendations, based on a study of the fox Vulpes. Mammal Review, 21(3): 97-122.

Richter M. 2003. Using Epiphytes and Soil Temperatures for Eco-Climatic Interpretations in Southern Ecuador (Der Nutzen von funktionalen Pflanzentypen und Bodentemperaturen für klimaökologische Interpretationen in Süd-Ecuador). Erdkunde, 57(3): 161-181.

Rivera RJ. 2007. Parque Nacioanal Podocarpus. En: ECOLAP y MAE. 2007. Guía del Patrimonio de Áreas Naturales Protegidas del Ecuador. ECOFUND, FAN. DarwinNet, IGM. Quito, Ecuador.

Romo MC. 1995. Food habits of the Andean fox (Pseudalopex culpaeus) and notes on the moutain cat (Felis colocolo) and puma (Felis concolor) in the Rio Abiseo National Park, Peru. Mammalia, 59(3): 335-344.

Rosellini S, Barja I, Piñeiro A. 2008. The response of the European pine marten (Martes L.) feeding to the changes of small mammal abundance. Polish Journal of Ecology, 56:497-504.

Rubio AV, Alvarado R, Bonacic C. 2013. Introduced European rabbit as main prey of the native carnivore culpeo fox ( $L y$ calopex culpaeus) in disturbed ecosystems of central Chile. Studies on Neotropical Fauna and Environment, 48(2): 89-94.

Shannon CE, Weaver W. 1949. The mathematical theory of information. Univ. Illinois Press. Urbana.

Sierra M. 1999. Propuesta preliminar de un sistema de clasificación de vegetación para el Ecuador continental. Proyecto Inefan/Gef-Birf y Ecociencia. 194 pp.

Sillero-Zubiri C, Hoffmann M, Macdonald DW. (Eds.). 2004. Canids: foxes, wolves, jackals and dogs: status survey and conservation action plan. IUCN.

Silva SI, Bozinovic F, Jaksic FM. 2005. Frugivory and seed dispersal by foxes in relation to mammalian prey abundance in a semiarid thornscrub. Austral Ecology, 30(7): 739-746.

Sokal RR, Rohlf FJ. 1981. Biometry Freeman. New York, 859.

StatSoft Inc. 2011. STATISTICA (data analysis software system), version 10. www.statsoft.com.

Stucchi M, Figueroa J. 2010. Descripción de las interacciones tróficas entre el cóndor andino Vultur gryphus y otras especies por el consumo de carroña en el cañón del Colca, Arequipa. Boletín Informativo de la Unión de Ornitólogos de Perú, 5(2): 8-14.

Tirira D. 2007. Guía de Campo de los Mamíferos del Ecuador. Quito: Ediciones Murcilago Blanco. Shuttle Radar Topography Mission, 3.

Tirira D. 2011. Lobo de Páramo (Pseudalopex culpaeus). Pp. 215-216, en: Libro Rojo de los mamíferos del Ecuador (D.G. 
Tirira, ed.), 2a. edición. Fundación Mamíferos y Conservación, Pontificia Universidad Católica del Ecuador y Ministerio del Ambiente del Ecuador. Quito.

Walker RS, Novaro AJ, Perovic P, Palacios R, Donadio E, Lucherini M, López MS. 2007. Diets of three species of Andean carnivores in high-altitude deserts of Argentina. Journal of Mammalogy, 88(2): 519-525.

Zacari MÁ, Pacheco LF. 2005. Depredación vs. problemas sanitarios como causas de mortalidad de ganado camélido en el Parque Nacional Sajama. Ecología en Bolivia, 40(2): 58-61.

Zapata SC, Travaini A, Delibes M, Martínez-Peck R. 2005. Food habits and resource partitioning between grey and culpeo foxes in southeastern Argentine Patagonia. Studies on Neotropical Fauna and Environment, 40(2): 97-103.

Received: 7 September 2016

Revised and accepted: 19 April 2017

Published online: 19 July 2017

Editor: V. Nijman 